\title{
Hoe benader en hanteer 'n Christenprediker die Ou Testament?
}

$J L$ Helberg, Potchefstroom

\begin{abstract}
How does a christian preacher approach the Old Testament? The interpreter-preacher has to do with the authoritative Word of God, the absolute source and standard before which the listener (and the preacher himself) have to yield. The preacher has to lay down himself and his preferences. The name "Old Testament" implies that a turning-point has occured. It does not imply a change regarding the essence of the proclamation but it concerns the fulfilment in the historical coming of the Person Jesus Christ. The Triune God must be proclaimed in a nuanced way in every sermon. Every sermon must be revelation-historical and must involve the past, the present and the eschatological future. It must be kingdompreaching, not national-preaching and it implies atonement, forgiveness and love as well as a summons to repentance, selfdenial and reformation.
\end{abstract}

\section{INLEIDING}

In my boek "Verklaring en prediking van die Ou Testament" (1983:113116: vgl ook 93-102) word 'n kort beskrywing gegee oor openbaringshistoriese prediking en oor elemente in die prediking. Hierdie artikel bou op dieselfde uitgangspunte sonder om op almal direk in te gaan. Die aandag sal op elemente gevestig word wat nie vroeër behandel is nie, en ander sal breer bespreek word. Die fokus sal veral geplaas word op die feit dat die prediker met die Oú Testament te doen het en op wat die implikasies daarvan vir die Christenprediker is.

Daar sal op gewys word dat die Ou Testament deel vorm van 'n groter geheel en dus nie alleen staan nie. Dit kan nie op homself gelees of verklaar word nie, hoewel dit vir homself moet praat en daar nie gedagtes ingelees moet word nie. Dit moet gelees word in die lig van sy verlenging, sy vervulling in Jesus Christus. Die naam Ou Testament wys daarop dat daar in en deur Christus 'n ingrypende wending plaasgevind het wat vir die prediking van die Ou Testament van beslissende betekenis is en 'n nuwe aksent daarin bring. Prediking impliseer dus dat Christus gepreek word. Dit het veral te doen met versoening, met vergewing van sondes en met liefde, asook met 'n oproep tot bekering en met self verloening teenoor die soewereine wil van God.

Die Ou Testament verkondig die mislukking van die mensdom, ook van die volk van God. Hierdie verkondiging het belangrike implikasies vir die prediking vandag. 
Die prediking het te doen met die Woord van God, en wel soos dit gestalte gekry het in die Skrifte, saamgevat in die Kanon wat die Ou en Nuwe Testament omvat. Die verhouding tussen die Ou Testament en die Nuwe Testament moet reg gesien word, veral hoe die volkskap van Israel en ook van die gelowiges van vandag daardeur geraak word.

God tree herskeppend en verlossend op vir sy volk. Hierin speel die Gees van God 'n belangrike rol, veral volgens die verkondiging vanaf die ballingskapstyd. Die Gees is dus van wesenlike belang vir en in die prediking

Die Ou Testament word gekenmerk deur 'n toekomsperspektief of eskatologiese perspektief; dit hang saam met 'n sterk beloftekarakter en het implikasies vir 'n eskatologiese roepingsbesef wat ook op die hede gerig is.

Hierdie verskillende aspekte sal hieronder nader bespreek word.

\section{DIE "OU TESTAMENT"}

\section{1 'n Wending}

Die Jode wat nie Christene is nie, aanvaar nie die Nuwe Testament as die Skrif en praat nie van die Ou Testament as die Ou Testament nie, maar as die Hebreeuse Bybel. Dit word deur hulle nie gelees teen die agtergrond van die ingrypende gebeurtenis van die koms van Christus en die verandering wat daarmee geassosieer word nie.

Wie die naam "Ou Testament" gebruik, stel daarmee 'n standpunt in verband met die Bybel. Dit sẽ dat die Ou Testament 'n deel is van die Bybel, wat bestaan uit die Ou Testament en die Nuwe Testament. Verder word met dié naam bely dat daar 'n historiese gebeurtenis van ingrypende aard plaasgevind het. Dit was so ingrypend dat die een testament die Ou Testament geword het. Hy kan dus nie meer net so, soos hy is, gelees, verklaar en gepreek word nie.

Die verandering waarvan hier ter sprake is, is nie 'n verandering van godsdienstige idee of leer nie (vgl bv Bright, 1967: 130; 1953: 195; Helberg, 1983: 97-102). Die Nuwe Testament verkondig wel die vervulling, of gedeeltelike, aanvanklike vervulling van wat in die Ou Testament verkondig is. Hierdie vervulling is reeds deur die Ou Testament self in vooruitsig gestel, soos blyk uit die verkondiging van die nuwe eksodus of uittog (veral in Jes $40 \mathrm{ev}$ ) en die nuwe verbond in Jeremia $31: 31$ - 34 (vgl bv Bright, 1953:202) en die aankondigings van die koms van die Verlosser (bv Jes 9:16; 11:1-2; 52:13-53:12; Dan 7:13). Jesus Christus het self uitdruklik verklaar dat Hy nie gekom het om die wet of die profete ongeldig te maak nie maar om hulle hulle volle betekenis te laat kry (Matt 5:17).

Daar kan dus nie met Bultmann se beskouing saamgestem word (vgl Helberg. 1983:23. 24) waar hy die verskil tussen Ou Testament en die Nuwe Testament verabsoluteer nie. Dieselfde geld van Baumgärtel (1968:114, 132) wat van die Ou Testament as 'n vreemde woord uit 'n vreemde religie praat. Volgens Bultmann se beskouing (1968:50-53) leer die $\mathrm{Ou}$ Testament nie slegs dat die mensdom, en ook die volk van God, 'n mis- 
lukking is nie, maar is die Ou Testament self in 'n sekere sin 'n mislukking. Bultmann benader die Ou Testament eksistensialisties. Die mens moet volgens hom tot 'n nuwe selfverstaan kom deur die geloof. Die teks se verkondiging kan alleen verstaan word deur iemand wat gedring word deur die vraag na sy eie eksistensie, deur sy voorafverstaan (Vorverständnis). Bultmann laat die geloof dus aan die Bybel voorafgaan in plaas van die geloof op die Bybel te laat rus.

Volgens Bultmann hoor die Christen die Woord van God in die Ou Testament slegs indirek. Die Ou Testament se begrip van die mens se eksistensie, saam met die Ou Testament se radikale beslaglegging op die hele lewe van die mens, is dieselfde as die van die Nuwe Testament. Die Ou Testament het egter slegs 'n opvoedingsfunksie om die hoor en verstaan van die evangelie voor te berei. Die Ou Testament bevat nie heilsgeskiedenis, wat op Christus uitloop nie. Dit is inteendeel 'n geskiedenis van mislukking, 'n geskiedenis van teleurstelling vir die hoop van Israel. So is dit 'n leermeester tot Christus (Gal 3:24). Hierdie geskiedenis van verydelde hoop en van mislukking, saam met die eise wat die wet stel, bring die leser tot die besef van die teenstelling in sy menslike eksistensie. Dit is die teenstelling om deur God geroep te wees en tog aan die aarde gebonde te wees. Die mens se besef van sy eie mislukking dryf hom dan uit na berou en na die aanvaarding dat regverdigmaking deur die geloof alleen kom. Die Ou Testament is nie absoluut nodig nie, want wat die Ou Testament die mens oor die aard van sy eksistensie leer, kan feitlik oral in die menslike ervaring opgedoen word.

Bultmann se eksistensialistiese benadering maak dat hy teen die menslike mislukking in die Ou Testament vaskyk en nie die liglyn van God se openbaringshistoriese optrede raaksien nie. God werk lewewekkend. Hy wek vooruitgang uit mislukking, voorspoed uit ondergang, lewe uit dood. Die mislukking van Israel, beliggaam in die ballingskap, laat juis die messiaanse verwagtings opbloei. Sterwe en opstanding slaan juis in die Ou Testament deur (Eseg 37).

In aansluiting by wat hier bo oor Jesus se woorde in Matt 5*: 17 gesê is, kan die volgende gestel word:

Die ingrypende gebeurtenis waardeur daar 'n ou bedeling en 'n nuwe bedeling. 'n ou verbond en 'n nuwe verbond, 'n Ou Testament en 'n Nuwe Testament tot stand gekom het, konsentreer in 'n Persoon. Dit gaan om 'n Persoon wat middelaar of versoener is tussen God en die mense. God het Homself ten volle aan ons gegee in Christus. Hy eis ons ten volle op. Ook rus Hy ons ten volle toe.

Die naam Ou Testament verkondig dus 'n Goddelike ingryping in die geskiedenis, 'n ingrypende wending. Tegelykertyd eis dit ook ' $n$ wending. 'n volledige ommekeer, in benadering, denke, gesindheid, houding en verhoudinge. Jesus Christus maak alles nuut. Die naam Ou Testament impliseer dus dat die prediking Christusprediking moet wees; dit beteken verkondiging van versoening met God en vergewing van sondes in Jesus Christus. 


\subsection{Versoening, vergifnis en liefde}

Vanaf die eerste hoofstukke van Genesis en dwarsdeur die Ou Testament kom die volgende soos ' $n$ refrein voor: sonde, genade, vergifnis. Dit gaan gepaard met 'n oproep tot bekering. Die Ou Testament het te doen met gemeenskap van mense met God en met mekaar. Volgens Jesus Christus handel die kern van die wet en die profete oor liefde in ' $n$ mens se optrede en verhoudinge. Dit kry op 'n unieke manier gestalte in Jesus Christus self. Daarom verkondig die Christenprediker 'n unieke boodskap, ook in sy prediking van die Ou Testament. Ander verkondigings het te doen met wat profeet, priester of koning geeis het en nog eis. Die Christenprediker daarenteen, verkondig wat Christus in liefde en self verloening gedoen het, en veral wat Hy met Hom laat gebeur het. Dit is 'n vervulling van die $\mathrm{Ou}$-Testamentiese verkondiging, soos saamgetrek in die liedere oor die lydende dienaar van die Here (veral in Jesaja 53). Hy soek nie Homself of sy voordeel nie, maar die van ander. So verklaar Jesus Christus die Ou Testament met woord en daad.

Die verkondiging van die Ou Testament onderskei hom daarin van dié van ander godsdienste dat hy daarop klem lê dat daar net een God is, naamlik Jahwe, die Here. Hierdie verkondiging is veral saamgevat in Deuteronomium $6: 4$ : "Luister, Israel, die Here is ons God, Hy is die enigste Here". Dit is verbind met die eis om God lief te hê: "Daarom moet jy die Here jou God liefhê met hart en siel, met al jou krag"'. In Christus word die konsekwensies hiervan deurgetrek, verbind met die tweede tafel van die wet, soos weergegee in Levitikus 19 : 18: "Jy moet jou naaste liefhê soos jouself"'. Liefde, selfverloëning, diensbaarheid is die deurslaggewende gesindheid in alle verhoudinge en optrede. Jesus Christus wil iets hiervan ook in die gelowiges se lewe afgebeeld sien (Matt 5:3-16). Die prediking van die Ou Testament moet hiervan erns maak.

\section{3 'n Totale selfverloëning by die prediker}

Reeds in die Ou 'Testament word daar ' $n$ totaal ander instelling as die gewone by die prediker geëis. Dit korn veral in die opdrag aan die profete duidelik na vore. Hulle moet 'n totaal ander boodskap bring as dié van die gewone lewe of gewone denke. Dit begin met 'n totaal nuwe instelling van die verkondiger teenoor homself en sy gedagtes en insigte. Hy moet homself aflê. Sy prediking moet die getuienis lewer van iemand wat deur hierdie meule gegaan het. Jeremia, Esegiel, Amos en Jona is sprekende voorbeelde hiervan. Jeremia beklaag sy lot om die boodskap te moet bring wat so anders is as wat hy self graag sou wou verkondig: " $U$ het my mislei, Here, en ek het my laat mislei. U was te sterk vir my, $U$ het gewen" (Jer 20:7). Esegiël kla gedurig dat die mag van die Here hom in besit geneem het en swaar op hom gedruk het om die Goddelike Woord te verkondig (vgl bv Eseg $3: 14,22 ; 8: 2 ;$ ens.). Amos vergelyk die Goddelike opdrag om as profeet op te tree, met die angswekkende brul van 'n leeu: "Die leeu het gebrul, wie sal nie bang wees nie? Die Here God het gepraat, wie sal nie as profeet optree nie?" (Am 3:8). Jona kry 'n opdrag en word gedwing om te doen wat hy glad nie wil doen nie en waarvoor hy letterlik wegvlug (Jona 1:3). God laat hom nie aan homself oor nie 
en konfronteer hom met die eis om sy gedagtes, gesindheid en instelling radikaal te verander (Jona 4:1-10).

Die eis dat die profeet, en gevolglik ook die prediker, homself en sy oorwegings moet aflē, kom ook duidelik na vore by Samuel en Natan. Hulle ontvang albei 'n opdrag van die Here om af te sien van hulle onderskeie sienings, sieninge wat volgens gewoon menslike oorwegings die logiese en regte is. Samuel moet teen sy sin vir die volk 'n koning aanstel, ondanks die feit dat hulle versoek om 'n koning verkeerd is (1 Sam 8). Natan moet sy advies aan Dawid dat hy vir die Here 'n tempel mag bou, herroep. Hy moet aan Dawid sê dat die Here hierdie versoek weier, hoewel Dawid se seun die tempel sal mag bou (2 Sam 7).

Die voorbeeld van Natan wys dat selfs die prediker se beste bedoelings en sy optrede wat in goedertrou gedoen word, nie goed genoeg is nie. Daar word 'n ander maatstaf vereis. Profeetwees hou in om jouself, jou gedagtes, wil en oorwegings af te lê teenoor God se vrymagtige wil. Jy moet net God se wil verkondig. En God se wil en oorwegings staan gewoonlik teenoor die profeet of prediker se wil en oorwegings. Die verkondiger moet in die volle sin van die woord sê: "So sê die Here". Die hoorders moet hierdie verskil kan hoor, hierdie veranderde instelling, hierdie aflegging van jouself as prediker. Hulle moet gewaar word dat hulle met God en sy wil gekonfronteer word, nie met die prediker s'n nie - hoe goed sy bedoelings ook al is.

Die prediker moet hom veral nie self mislei en te maklik aanneem dat hy aan die vereistes en oorwegings van 'n ware verkondiger voldoen nie. Die woorde "So sê die Here" is nie net deur ware profete gebruik nie, maar algemeen, ook deur valse profete. Dit lè juis in die aard van die sondige mens, van elke prediker, om op subtiele manier vir sy eie oorwegings Goddelike sanksie te verkry. Hy doen dit veral deur 'n beroep op die Goddelike wil, soos in die formule "So sê die Here".

Die voorbeelde van Samuel en van Natan bevat ' $n$ belangrike waarskuwing: selfs waar die prediker reg ingestel is teenoor 'n saak of probleem, soos Samuel teenoor die volk se versoek om 'n koning, moet hy beskeie en met selfverloening optree. God se wil en gedagtes val nie saam met menslike oorwegings, beplannings, bewegings en stelsels nie.

Om hierdie rede is dit verkeerd en is dit ' $n$ wesenlike aantasting van die prediker se profetiese roeping, as hy ' $n$ politieke partybeleid verkondig: Nasionale Partybeleid, of Konserwatiewe Partybeleid, of HNPbeleid, of PFP-beleid, of UDF-beleid, of wat ook al. Die prediker wat hom in sy prediking met een van hierdie groepe identifiseer, kan nie met reg sê dat hy deur God geroep en gestuur word nie. Inteendeel, in so 'n geval het daar 'n subtiele verskuiwing ingetree en word die prediker, selfs onbewus, 'n geroepene en gestuurde en woordvoerder vir 'n bepaalde idee of stelsel. Wie in sy prediking nie al die genoemde groepe persone of stelsels aanspreek en konfronteer en tot konkrete bekering en reformasie oproep nie, faal in sy profetiese roeping.

Profeetwees het in Israel beteken om 'n korrektief en kontrole te wees op die koning en ander owerhede (vgl bv Helberg. 1988:117). 
Dit beteken nie dat 'n prediker die rol van kritikus moet vervul of 'n opposisie-mentaliteit moet vertoon nie. Hy moet egter die samelewing en die owerhede as 't ware met die Woord van God begelei. Hy mag nie deur die samelewingspatrone en -stelsels en owerhede geabsorbeer word nie, maar moet deur die Woord sy selfstandigheid as Woordverkondiger behou. Daarvoor moet hy in die eerste plek, met die Woord, sy selfstandigheid teenoor homself behou.

Die Gereformeerde prediker wat só na die Woord luister, sal ook tot die besef kom dat die Woord nie dieselfde is as calvinisme nie. Ook hier het die prediker 'n korrektiewe taak. Nie calvinisme is ons bron en maatstaf nie, maar die Woord van God alleen, die Woord wat met sy deurdringende strale dwarsdeur alles skyn en die krake, vergroeiings, vlekke en dowwe kolle daarin aan die lig bring. Die Gereformeerde prediker het ook 'n korrektiewe taak teenoor gereformeerdheid, en teenoor die Gereformeerde kerke. Die Ou Testament is een lang verkondiging van die mislukking van Israel, die volk van God. Ware Skrifprediking kan die volk van God, die kerk, nie net troetel nie. Ware Skrifprediking is gereformeerde prediking, reformerende prediking: selfondersoekend, selfontdekkend, gerig op bekering.

\subsection{Menslike mislukking}

Die begrip "Ou Testament" impliseer mislukking. Die Ou Testament praat dan ook van begin tot end van die mislukking van die mensdom in die geheel en van die verbondsvolk in besonder. Daar sal 'n nuwe verbond, 'n nuwe testament, kom - sê die Here deur die profeet Jeremia - want Israel het My vergeet (Jer 31:31-34). In Israel sien ons die spieelbeeld van onsself. In Israel se mislukking sien ons ons mislukking.

'n Kerk wat die Woord van God ernstig neem, bely hierdie leemte by homself - nie net vaag, teoreties en algemeen nie, maar konkreet en prakties. Dit beteken dat die belydenis van die Heidelbergse Kategismus ernstig geneem word: ons is van nature geneig om God en ons naaste te haat (Heid Kat $\mathrm{Vr} 5$ ). In die praktyk wil 'n mens eerder die ander rigting inslaan. Jy wil jou kerk sien as vlekloos en in alles reg: in sy geskiedenis, in sy inrigting, in sy tradisie, in sy verhoudinge met ander. Die kerke en predikers moet egter van hierdie gesindheid ontslae raak, soos die ware profete moes doen in onderskeiding van die ontroue profete. Hulle moet deur dieselfde meule gaan. Hulle moet besef wat dit beteken om uit genade te leef in teenstelling met om uit verdienste te leef.

Die Skrif waarsku teen selftevredenheid. Die profete kan nie uitgepraat raak daaroor nie. Israel se selftevrede benadering van die verbond het dan ook gemaak dat sommige profete die begrip verbond vermy het (vgl bv Amos en Jes 1-39). Om dieselfde rede ontbreek die formule "Ek is Jahwe julle God" byna heeltemal by die profete (Jeremia en Esegiel vermy dit skynbaar; dit word eers weer in die ballingskap in ere herstel - aldus Elliger, $1966: 224,225,230,231$ ). Die profete het dit ook teen skynbare nederigheid, skynbare ootmoed, ook teen 'n gesindheid wat die vyand net elders soek, wat die vyand van God net raaksien in ander rigtings, stelsels, -ismes en kerke. By so 'n gesindheid het daar 'n verskuiwing 
van fokus plaasgevind. Die stryd is dan nie meer teen die Bose, teen die sonde nie, en daarom ook nie teen die eie hart en kerk nie. Nie die sonde word dan beveg nie, nie die sondigheid soos in eie boesem nie, maar stelsels en strukture. Die Ou Testament daarenteen is konkreet in sy aanwysing van die sonde en doen dit gewoonlik op die man en die daad af. Dit is veral die hoorder wat op sy sonde gewys word. Hy word nie ' $n$ toeskouer gemaak van ander, afwesiges, se sondes nie, maar word tot selfontdekking gebring. Amos is 'n goeie voorbeeld van so 'n prediking. Hy verras sy hoorders deur met ' $n$ oordeelsaankondiging van God oor die heidennasies te begin, maar die kring dan nouer te trek totdat sy gehoor ingesluit word (Am 1-2). Hy ontnugter die verbondsvolk deur te sê dat uitverkiesing vir hulle oordeel in plaas van redding inhou weens hulle sondes (Am 3:2;5:18-20). Hy kla die bevoorregtes, insluitende die geestelike leiers, aan dat hulle die minderbevoorregtes veronreg en daarmee die verbondsverhouding met God verbreek het.

Ware prediking van die $\mathrm{Ou}$ Testament plaas die hoorder in sy menslike kleinheid en nietigheid voor die soewereiniteit of vrymag van God, en in sy menslike sondigheid voor die heiligheid van God. Dit roep op tot berou. Daarmee word die hoorder gestel voor God se verlossende genade, voor die wesenlike betekenis van sola gratia: uit genade alleen. Dit hang saam met die ewe bekende reformatoriese uitdrukking sola Scriptura: die Woord alleen. Dit bring ons by die volgende punt.

\section{DIE WOORD AS SKRIF}

Die nuwe bedeling, Nuwe Verbond, of Nuwe Testament, bestaan nie bloot daarin dat God aan mense die gesindheid van gehoorsaamheid sal gee deur sy wet slegs in hulle hart en op hulle verstand te skrywe nie. Die Woord sal nie uit die mens se hart opkom nie. Trouens, hoewel ons die Woord uit die hand van Israel en van die kerk ontvang het, is dit nie die Woord van Israel of die Woord van die kerk nie. Hierdie Woord gaan inteendeel teen Israel en teen die kerk in en is 'n korrektief op Israel en op die kerk. Childs (1979:40.58, 59, 74) sê dan ook tereg dat die Ou Testament nie die gemeente se eie uitvinding is nie, nie Israel se verstaan van sake of sy selfverstaan nie. Die Bybel bied nie 'n relasionele waarheid, 'n betreklike waarheid waarin die hoorder, of die prediker, van vandag 'n wesenlike inset moet of kan lewer nie (vgl hieroor Weijland e.a., 1982: Helberg 1983:35, 36). Inteendeel, die Bybel bied homself aan as die Woord van God wat vir alle tye vasstaan. In hierdie Woord word die hoorder in sy persoonlike omstandighede deur die Heilige Gees met God gekonfronteer.

Reeds in die Ou Testament is daar ' $n$ tendens om die openbaring van God vir alle tye te laat vaslê, soos in die verskynsel van die reënboog (Gen 9), die gedurige teruggrype op die uittog uit Egipte, die opdrag om die werke van God aan die kinders te vertel, die opdrag om die wet op te teken, en so ook die profetiese verkondiging (vgl bv Helberg. 1983:74).

Christus verwys na die wet en die profete en na "die Skrif" of "die Skrifte" as gesagvolle Woord van God. Hy het nie gekom om hulle ongeldig te maak nie, maar om hulle hulle volle betekenis te laat kry

In die Skriflig 1989, 23 (1) - 11 
(Matt 5:17). Die betekenis van die Skrif moet vasgehou word en nie verswak word, soos Gunneweg doen deur die fokus na die verkondiging (om Christus te verkondig) te verskuif nie (vgl bv Boshoff, 1987:371).

Die Ou Testament vorm 'n eenheid, word deur Christus as 'n eenheid behandel, en moet as 'n eenheid gepreek word. Die prediker moet daarom nie 'n teks bloot op homself bekyk nie, maar moet erns maak met die verband waarin dit staan. Daarvoor moet aandag gegee word aan die perikoop, hoofstuk, groep hoofstukke, Bybelboek en Testament. Verder moet aandag gegee word aan die verhouding van die twee Testamente, aangesien die openbaring van God saamtrek in Jesus Christus. Die Woord is aan ons in literêre vorm, as 'n geskrif of geskrifte gegee. Daarom moet daar ook aandag gegee word aan die literêre hoedanighede en vereistes van verklaring van die verskillende soorte stof. Hierop kan nie hier ingegaan word nie. Sommige hiervan sal wel in die ander artikels behandel word. Kort saamgevat, kom dit wat gesê is daarop neer dat die verklaring van die Ou Testament openbaringshistories moet wees.

\section{DIE VERHOUDING OU TESTAMENT-NUWE TESTAMENT EN VOLKSKAP}

Dit is van die grootste belang dat die prediker die verhouding Ou Testament - Nuwe Testament reg moet sien. Dit vereis dat die betekenis van Christus reg gesien moet word. Christus is die middelaar tussen mens en God en is in hierdie opsig sentraal. Die fokus is nie op Israel as bemiddelaar nie. Met die koms van Christus het daar 'n ingrypende verandering ingetree (vgl Ef 3:5,6): volk en kerk val nie saam soos dit in 'n mate in die ou bedeling die geval was nie. Hierdie feit is van wesenlike betekenis, veral in ons land vandag. Daarom moet die prediker hom grondig hieroor verantwoord. Dit raak 'n fundamentele hermeneutiese saak en beinvloed en bepaal selfs hoe ' $n$ mens die Bybel lees en verklaar - of dit raak is en of dit mis is (vgl oor hierdie problematiek bv Rendtorff, 1975:20, 21: Bachli, 1962:226; Oosterhoff, 1973:46. 48: Verhoef, 1967:70-76; 1987:31, 32; Brueggemann, 1978: 170-183).

Daar bestaan die gevaar om in die verhouding Ou Testament-Nuwe Testament, een faset van die Ou Testament te laat oorheers in plaas van Christus, naamlik om volkskap oorheersend te maak. Die sieutel vir die benadering van sake, mense, samelewing en kerk word dan volkskap in plaas van die geloof in Jesus Christus. Hierdie tendens tot 'n volkse sleutel kom voor by "gangbare" teologie sowel as by horisontalistiese teologieë, soos bevrydingsteologiee. By laasgenoemde is die volkskapsleutel net in ander gewaad gehul en vanuit 'n opponerende hoek benader.

Daar is ook ' $n$ benadering wat alles vergeestelik, wat geen oop oog het vir die Ou Testament se deurlopende gerigtheid op die konkrete werklikheid en sy sin vir die kulturele en die volkse, vir taal ensovoorts nie.

Die prediker moet nie tussen dié twee soorte benaderings skipper nie. Hy moet nie in die strik trap om met 'n sleutel soos "eenheid én verskei- 
denheid" te werk, soos ons so graag en ter goeder trou doen nie. Hierdie soort benadering werk in werklikheid met ' $n$ abstraksie, met iets bloedloos, met 'n onpersoonlike groepering. Die tweërlei groepering wat sodoende ontstaan - eenheid en verskeidenheid - word teen mekaar opgeweeg en die fokus word verkeerdelik daarop gevestig in plaas van op Jesus Christus. Dit gaan in die Skrif nie om die sake, of entiteite, eenheid en verskeidenheid nie, maar om Christus, en om eenwees in Christus. Dit gaan om die persoonlike verhouding met Christus, en om die eenwees en gemeenskap met dié wat in Christus glo. Dit gaan dus in die eerste plek om iets persoonliks, nie om iets wat groepsbepaald, institusioneel bepaald of struktureel bepaald is nie.

Christus is sentraal en omvattend, Hy is allesbeheersend. Hy gee sin aan alles, ook aan verskeidenheid van gawes, kultuur en taal. Die feit van sy menswording en sy bggaamlike opstanding bevestig die betekenis van die materiële werklikhede en gee dit meer waarde, nie minder waarde nie. Tegelykertyd relativeer Hy egter alles en maak dit ondergeskik en diensbaar aan die verhouding met Hom. Dit word 'n middel in die gemeenskaplike doel, naamlik die beywering vir die koninkryk van God. Daarin lê hierdie dinge se sin en waarde; ook hulle grense. Hulle moet die gemeenskap van die gelowiges bevorder, nie strem nie. Die kerk moet hierdie kenmerk vertoon, veral in die prediking. Die kerk is God se kerk, kerk van Jesus Christus, van Hom alleen, nie mense s'n nie, nie ons s'n nie. Die prediker in ons land het veral 'n groot verantwoordelikheid voor God om, so onbevange moontlik, voortdurend die Skrif hieroor te ondersoek en dit te laat praat. Dit gaan hier trouens om een van die aktueelste en delikaatste aspekte van kerkwees in ons land. Geen kerk ontkom vandag aan die probleme hieraan verbonde en aan die toets wat God oor ware kerkwees hierin stel nie.

\section{DIE HEILIGE GEES}

L.: Ou Testament leer dat die mens nie uit homself daartoe kan kom om God te dien, om God en sy naaste lief te hê nie. Die geskiedenis van die mensdom, ook die van Israel, is 'n geskiedenis van mislukking. Die geskiedenis van Israel loop uiteindelik selfs uit op die ballingskap. Esegiël beskryf dit as die dood van die volk. Tegelykertyd beskryf Esegiel die wonderbaarlike, Goddelike ingryping: lewewekking, herskepping van Israel deur die Heilige Gees (vgl bv Vos, 1985:78).

Vanaf die ballingskapstyd, wat in 'n sekere sin die laagtepunt sowel as die klimaks van Israel se geskiedenis vorm, word daar in die Ou Testament ál sterker van die werk van die Gees gepraat. Esegiel verbind die Gees met die nuwe verbond. Jeremia swyg oor die Gees, moontlik omdat daar 'n valse beroep op die werking van die Gees gedoen is deur ekstatiese of ander profete. Vosloo (1983:51-53) meen dit is omdat die Gees met $\mathrm{krag}$ te doen het terwyl die werk van die profete eerder gekenmerk is deur die afwesigheid van kragoptrede. Die valse beroep op die werking van die Gees gee egter 'n aanvaarbaarder rede waarom die Gees aanvanklik ook nie verbind is met die Woord van God nie. Dit word wel gedoen in Jesaja 59:21. In die na-ballingskapse tyd word ook die profesie, 
Insluitende die vroeëre profesie, aan die Gees toegeskryf (Neh 9:30; Sag 7:12; Miga 3:8; vgl Albertz/Westermann, 1976:746).

Volgens Esegiel 37 bewerk die Gees die onmoontlike: 'n wedergeboorte, bekering, ' $n$ lewe van gehoorsaamheid aan God se gebooie. Die Gees het verder nie net met die geestelike sfeer te doen nie, maar ook met die ampstoerusting van rigters en konings (vgl bv Jes $11: 2 ; 42: 1 ; 61: 1)$ en van handwerkers (Eks 31:3; 35:31). Verder het die Gees te doen met God se werksaamheid in die skepping en die geskiedenis (Gen 1:2; Ps 33:6, 7; Jes $40: 12-31 ; 44: 3-28$ ).

Reeds die eerste verse van die Ou Testament praat oor die Gees van God wat op een of ander manier met die skeppende werksaamheid van God besig is. (Die vertaling "wind van God" - "groot storm", is omstrede, vgl bv Albertz/Westermann, 1976:729, 730.)

In die tyd vanaf die ballingskap word die werking van die Gees nie net met konings en ander besondere persone verbind nie, maar met die hele volk (vgl Jes 32:15; 44:3; Eseg 36:27; 39:29: Joel 2:28, 29). Die Gees het veral te doen met die wonderbaarlike Goddelike redding en sy beskerming in 'n hopelose situasie, en met sy trou op grond van die ou verbond te Sinai (Hag 2:5); en verder met die toerusting vir die lewe met God en in sy diens. Die Gees bring die volk en die natuur tot lewe (Jes 32:15; Ps 104:30; Jes 11:4-9) (vgl Vosloo, 1983:60).

Die werking van die Gees is in die nuwe bedeling ten nouste verbind met Christus. Sy opstanding word bewerk deur die krag van die Heilige Gees, terwyl sy hemelvaart en sy sit aan die regterhand van die Vader opgevolg word deur die uitstorting van die Heilige Gees (Hand 2). Die Gees vorm die beginsel en krag van die gelowiges se nuwe lewe. Hy konfronteer die gelowiges met die Woord van God. Deur sy herskeppende krag bring hy hulle tot ommekeer, tot onderwerping aan die Woord en tot diensbaarheid aan God.

Heilige Gees-prediking is daarom 'n wesenlike element van elke preek, noewel dit gewoonlik, net soos die Christusprediking, nie direk uit die Ou-Testamentiese teks gehaal kan word nie, maar uit die vervulling in Christus (vgl ook Floor, 1987; Lion-Cachet, 1984).

\section{6. 'N ESKATOLOGIESE PERSPEKTIEF}

Soos reeds aangetoon verkondig die Ou Testament dat die mensdom, ook die gelowiges, deur en deur sondig en gebroke is en dus misluk het. Tegelykertyd verkondig die Ou Testament egter die wonderbaarlike, lewewekkende optrede van God. Hy bewerkstellig lewe uit ondergang en dood. Hy bring lewe en voortgang uit die dieptes van donkerheid, magteloosheid en verlorenheid. Die sondigheid, gebrokenheid en verlorenheid verdwyn nie; dit bly. Daarom bestaan daar 'n geweldige spanning in die mens se lewe: ondergang en voortgang, mislukking en seen staan soos hooggelaaide elektriese pole teenoor mekaar. Die $\mathrm{Ou}$ Testament verkondig verlossing wat is, maar wat tegelykertyd tog teruggehou word. Dit is iets wat ' $n$ mens alleen deur die geloof kan gryp en vashou, iets waarop jy as 't ware vooruitgryp. Dit is dus iets toekoms- 
tigs, iets eskatologies in die algemene sin van die woord (vgl oor die begrip eskatologie in algemene en in meer tegniese sin. Bright. 1976: 18. 19: vgl verder Preuss. 1968: 213. 214: Hanson, 1975: 16; Devries, 1975:282, 342-346; Terrien, 1978: 390; Vriezen. 1966:493, 494).

Hierdie eskatologiese perspektief kom in die Ou Testament reeds vanaf die vroegste tyd voor. Reeds Genesis 3 praat van die dodelike vyandskap tussen die mens en die slang en van die oorwinning wat daar vir die mens in die vooruitsig is ( $\mathrm{vgl} \mathrm{Helberg,} \mathrm{1988:26,27).}$

Die sondvloedgeskiedenis getuig van God se ingrypende bemoeienis met die mensdom waardeur Hy lewe uit ondergang bewerk en nuwe toekomsmoontlikhede skep (Gen 8:21). Dieselfde geld by die bou van die stad Babel en die roeping van Abraham wat daarop volg. Abraham ontvang die belofte van ' $n$ land, maar dit bly 'n beloofde land, wat selfs nie in die ander aartsvaders Isak en Jakob se lewe tot werklike volle vervulling kom nie. Hulle geskiedenis, en so ook die hele geskiedenis van die $\mathrm{Ou}$ Testament, is ' $n$ geskiedenis vol beloftes (vgl bv Kaiser. 1979 wat sy OuTestamentiese teologie om die belofte as sentrum bou). Selfs as die beloftes vervul word, is dit nog nie die finale punt nie, maar vloei daar gewoonlik verdere beloftes uit voort. Die Ou Testament staan oop na die toekoms toe, soos Von Rad (1958:99) dit stel (vgl. ook Brueggemann, 1978:16). Hierdie toekomsgerigtheid gee aan die Ou Testament 'n wydsheid van perspektief. Die gelowige se blik word nie bloot gerig op die hier en nou nie, maar die wye toekoms in. Dit verleen stukrag wanneer Israel in die moeilike omstandighede wil gaan lê. Selfs wanneer alle werklikhede skynbaar teen Israel was, het hulle nog op die beloftes van God bly hoop (vgl bv Bright, 1976:46). Daar is as 't ware vanaf die doellyn 'n onweerstaanbare trekkrag op hulle uitgeoefen.

Hierdie toekomsgerigtheid gee ' $n$ ander dimensie aan hulle realisme: die huidige realiteit word gedra deur 'n onuitwisbare idealisme en entoesiasme. Hulle hou vas aan 'n belofte wat nog vervul moet word n wat tegelykertyd gepaard gaan met 'n verpligting, 'n roeping wat hier en nou uitgevoer moet word, 'n eskatologiese bewoënheid en dryfkrag.

Hierdie eskatologiese bewoënheid en dryfkrag mag nie in die prediking ontbreek nie. Dit moet trouens 'n kenmerk van die hoorders word in alle verhoudinge, soos huweliksverhoudinge, kerklike verhoudinge en volksverhoudinge. Dit gaan om 'n lewensbenadering waarin nie net teen die huidige werklikheid vasgekyk word nie; om 'n sigbare, tasbare vooruitgrype op dit wat nog nie werklik kan word nie, maar waarvan tog 'n beginsel teenwoordig moet wees. Dit gaan om 'n gegrepenheid deur die koninkryk, 'n onuitblusbare idealisme ondanks dit wat nog nie kan realiseer nie. Hierdie soort gesindheid en instelling is uiters belangrik in die onderlinge verhoudinge. In hierdie verhoudinge is daar dikwels ' $n$ gevoel van vrugteloosheid en magteloosheid en frustrasie. ' $n$ Tasbare bewys van die ware gesindheid kan hieraan 'n einde maak, al is die situasie ver van ideaal. Die prediking moet 'n aansporing wees tot so 'n gesindheid en die skepping van so 'n atmosfeer. 'n Prediking waarin daar 'n eskatologiese perspektief is, laat iets voel van 'n vars luggie van die 
nuwe dag wat kom, waarvan daar nou iets in die geloof gegryp word. Die evangelie maak trouens alles nuut (Matt 13:51, 52; Joh 1:14; 3:3-21; 5:24; $6: 35$; ens.).

Die Ou Testament lê groot klem op die roeping teenoor die armes, die swakkes, dié wat geminag word, die minderbedeeldes, dié wat in nood is. Dit geld vir die huidige situasie sowel as vir die eskatologiese toekoms. Dit word duidelik gestel in die lofsang van Hanna (1 Sam 2:1-10) wat sy weerklank vind in die lofsang van Maria (Luk 1:46-55). Hiermee word nie 'n subtiel humanistiese koninkryk, 'n verdienstelikheidskoninkryk, 'n koninkryk van gekonsolideerde magteloses verkondig nie, maar die koninkryk van God wat dié insluit wat weet hoe afhanklik hulle van God is, Inaar die ander ontnugter. Ook die Psalms en die profete vertoon groot bewoenheid oor mense soos weduwees en wese en vreemdelinge, en roep die hoorders gedurig op om hulle roeping teenoor sulke mense na te kom (vgl bv Ps 68:6; 72:2, 4, 12, 13; 82:3; 112:9; 146:9; Jes 1:17, 23; $10: 2 ; 40: 2 ; 57: 13 ; 58: 13,14 ; 60: 21 ; 62: 11$; Jer $2: 34 ; 5: 28 ; 22: 3,13,15$, 16; Eseg 16:49; 18:12; 22:7, 29: Am 2:6; 4:1; 5:12; 8:4,6; Miga 6:6-8; Sag 7:10; Mal 3:5). Christus se koms en sy evangelie word ten nouste met sulke mense verbind (Matt 11:4,5).

Die samevatting of hoofinhoud van die wet en die profete, van die $\mathrm{Ou}$ Testament, is om God lief te hẻ met alles wat 'n mens is en het, en jou naaste soos jouself. Hierdie tweerlei element is trouens vervat in die tweedeligheid of twee tafels van die wet, waarvan die tweede oor 'n mens se verhouding tot jou naaste handel. Die verhouding tot die naaste is ' $n$ wesenlike element van die Ou-Testamentiese godsdiens. In hierdie tyd van horisontalisering, sekularisering en politisering van die evangelie, is dit veral nodig dat die prediker die suiwer Bybelse geluid laat hoor waarin albei tafels van die wet tot hulle reg kom. Alles moet binne die regte perspektief gestel word: liefde tot God. Waar dit egter sonder bewoenheid vir die armes, magteloses, eensames en vreemdelinge is - so sê die profete - is die verbond met God verbreek en word Hyself verag. Christus waarsku dat daar by sy koms groot ontnugtering sal wees omdat mense meen dat hulle met 'n mooi belydenis (Here, Here!) en aktiewe godsdiensbeoefening (wonders en uitdrywing van duiwels) God kan dien sonder om aan mense in hulle alledaagse nood aandag te gee (Matt 25:34-45)! Die prediker het dus 'n groot verantwoordelikheid om die mense voor te berei om Christus sonder ontnugtering, met vrede en vreugde te ontmoet. Die prediking moet groot erns maak met hierdie saak wat so belangrik is dat sekere aspekte daarvan spesiaal aan persone in die kerklike diens van diaken opgedra is.

\section{SAMEVATTING}

Die Ou Testament vorm deel van die Skrif, die gesagvolle Woord van God, die absolute bron en maatstaf waarvoor hoorder en prediker onvoorwaardelik moet buig. Dit vereis dat jy jouself en jou benadering van dinge ten volle moet aflê teenoor God se vrymag. Dit het geen waarde as 'n mens 'n suiwer belydenis oor die gesag van die Skrif het, maar die Bybel volgens jou eie standpunte verklaar nie. Prediking vereis 
dat die prediker moet vasstel wat God sê, en wat 'n teks oor God sê, want dit gaan om Hom en diensbaarheid aan sy wil (vgl ook Van der Walt, $1984)$.

Die begrip Ou Testament impliseer dat daar ' $n$ wending ingetree het, dat die Ou Testament in die lig van die Nuwe Testament benader en verklaar moet word, dit wil sê vanuit Christus. Dit het te doen met die verkondiging van sy lewe, sterwe en opstanding, van die Heilige Gees en van die wederkoms van Christus.

Die prediking van die Ou Testament impliseer versoening en vergewing in Christus, gepaard met 'n oproep tot bekering en reformasie, wat by die prediker en sy gehoor self begin. Dit is Gereformeerde prediking.

Die prediker preek eerstens vir die nuwe volk van God, die kerk van Christus, die gemeenskap van die gelowiges, nie die gemeenskap van volksgenote nie. Sy prediking is eerstens koninkryksprediking, nie volksprediking nie. Christus gee aan volkskap sin, maar tegelykertyd relativeer Hy dit ook in die gemeenskap met Hom en sy gelowiges.

Die Ou-Testamentiese verkondiging van die Gees loop deur in die Nuwe Testament en getuig van God se wonderbaarlike, lewewekkende werking in ons hart en lewe. Dit is 'n werking wat die gelowige anders laat optree as waartoe hy as sondaar geneig is, en wat dinge anders laat verloop as wat oenskynlik verwag kan word. Die gelowige se lewe word voortgestuwe deur 'n nuwe lewensbeginsel en deur onwrikbare, blymoedige hoop.

Die eskatologiese perspektief van die Ou Testament loop ewe-ens deur in die Nuwe Testament. Dit hang saam met Goddelike beloftes en met die roeping vir hier en nou. Dit bring idealisme en toewyding, veral in verband met die nood van armes en ander hulpeloses. Dit alles is die vrug van dankbaarheid vir wat God uit genade, in Christus, vir ons wat self swak en onwaardig is, doen.

Bogenoemde bespreking bring ons by basiese elemente vir elke preek, soos ek vanuit 'n ander hoek gestel het in Verklaring en prediking van die Ou Testament (Helberg, 1983:113-116). Elke preek moet die drie-enige God verkondig, die God wat is en wat was en wat kom. Die Ou Testament verkondig die drie-enige God nog ongenuanseerd; die Christusprediker moet dit in die lig van die koms van Christus en die Heilige Gees genuanseerd doen. Elke preek moet eksplisiet Christus-prediking bevat, wat handel oor hoe God deur Christus versoening bewerkstellig. Daarmee word moraliserende prediking uitgeskakel. So moet elke preek ook eksplisiet Heilige Gees-prediking bevat, wat handel oor hoe God deur die Heilige Gees in ons wat deur en deur sondig is, nuwe lewe, bekering en gehoorsaamheid bewerk. Daarmee word 'n prediking uitgeskakel wat net tot by die kruis, die dood van Christus kom, wat net handel oor wat Christus vir ons gedoen het, wat buite ons toedoen gebeur het, 'n prediking waarby ons passief bly. In Heilige Gees-prediking word daar gepreek oor Christus wat uit die dood opgestaan het, oor die lewende Christus, oor wat Christus in ons doen en hoe ons in en deur en met Hom 
lewe. Daarmee word tegelykertyd 'n prediking uitgeskakel wat 'n beroep doen op menslike geloof en aktiwiteit wat nie sy oorsprong en stukrag in God se inisiatief het nie.

Elke preek moet verder openbaringshistories wees deurdat dit die lyn van God se optrede deurtrek vanaf die verlede tot in die hede, met 'n eskatologiese visie op die hede en die toekoms wat die hoorder opwek tot daadkragtige roepingsbewustheid en blymoedige verwagting, en met 'n perspektief op die toekoms wanneer Christus sal kom. So word 'n tradisionalistiese en stagnerende prediking uitgeskakel wat die aksent eensydig op die verlede plaas; so word ook 'n aktualistiese of 'n eksistensialistiese prediking uitgeskakel wat die aksent eensydig op vandag plaas; en so word 'n vergeestelikende prediking uitgeskakel wat die huidige lewenswerklikheid ontvlug en die aksent eensydig op die hiernamaals plaas. Ware Skrifprediking verkondig die blye boodskap van verlossing gepaard met 'n oproep tot 'n lewe van bekering, reformasie en toewyding in die koninkryk van God - totdat Christus kom, wanneer God alles sal wees in almal.

\section{BIBLIOGRAFIE}

Albertz, R \& Westermann, C. 1976. ráah Geist. THAT II. Munchen: Kaiser. p. 726-753. Bächli, O. 1962. Israel und die Volker. Zurich: Zwingli.

Baumgärtel, F. 1968. Das hermeneutische Problem des Alten Testaments. (In Westermann, C, red. Probleme alttestamentlicher Hermeneutik. München: Kaiser. p. 114-139.)

Boshoff, PB. 1987. Eksistensiale verstaan van die Ou Testament: die teologiese arbeid van Antonius HJ Gunneweg. Hervormde Teologiese Studies, 43(3):352-373.

Bright, J. 1976. Covenant and promise: the prophetic understanding of the future in pre-exilic Israel. Philadelphia: Westminster. 1953. The kingdom of God. New York: Abingdon.

Brueggemann. W. 1978. The Land. London: SPCK.

Bultmann, R. 1968. Weissagung und Erfülung. (In Westermann, C, red Probleme alttestamentlicher Hermeneutik. Munchen: Kaiser. p. 28-53.)

Childs, BS. 1979. Introduction to the Old Testament as Scripture. London: SCM

Devries, SJ. 1975. Yesterday, today and tomorrow: time and history in the Old Testament, Grand Rapids: Eerdmans.

Elhger, K. 1966. Ich bin der Herr - euer Gott. (In Kleine Schriften zum Alten Testament. Zu seinem 65. Geburtstag. Theologische Bucherei, Manchen: Kaiser. p. 211-231.)

Floor, L. 1987. Die Heilige Gees en die prediking. In die Skriflig, 21(81) : 8-18, Maart.

Hanson. PD. 1975. The dawn of apocalyptic. Philadelphia: Fortress.

Helberg, JL. 1983. Verklaring en prediking van die Ou Testament. Potchefstroom: Administratiewe Buro (Potchefstroomse Teologiese Publikasies). 1988. Die Here regeer. Openbaringslyn deur die Ou Testament. Pretoria: NG-Kerkboekhandel.

Kaiser, WC. 1979. Toward an Old Testament theology. Grand Rapids: Zondervan.

Lion-Cachet. FN. 1984. Die prediking van Vader, Seun en Heilige Gees. (In Van der Walt, J. J. red. God aan die woord. Potchefstroom: Departement Diakonologie, PU vir CHO. p. 29-40.)

Oosterhoff, BJ. 1973. De beloften aan de aartsvaders. Kampen: Kok. (Verkenning en Bezinning.)

Preuss. HD. 1968. Jahweglaube und Zukunftserwartung. Stuttgart: Kohlhammer

Rendtorff. R. 1975. Israel und sein Land. Munchen: Kaiser.

Terrein, S. 1978. The elusive presence: toward a new Biblical theology. New York Harper \& Row. 
Van der Walt, JJ. 1984. Prediking wat God aan die woord laat kom. (In Van der Walt, JJ, red. God aan die Woord. Potchefstroom: Departement Diakonologie, PU vir CHO. p. 2-16).

Verhoef, PA. 1967. Israel in die krisis. Pretoria: NG Kerkboekhandel.

1987. Kerk en samelewing - wat sê die Ou Testament. Kaapstad: NG Kerkuitgewers. (Stellenbosse Teologiese Studies, 14.)

Von Rad, G. 1958. Verheissenes Land und Jahwes Land im Hexateuch. (In Gesammelte Studien zum Alten Testament 8. Munchen: Kaiser. p. 87-100.)

Vos, CJA. 1985. 'n Uitsig vanuit die kosmiese werk van die rüah op die pneumatologie? Skrif en Kerk, 6(1):70-89.

Vosloo, W. 1983. Ruah/gees in die Ou Testament. Skrif en Kerk, 4(2) :40-68.

Vriezen, ThC. 1966. Hoofdlijnen der theologie van het Oude Testament. Wageningen: Veenman.

Weijland, HB. ea. 1982. God with us. On the nature of the authority of Scripture. RES Theological Forum, 9(3\& 4), January. 